\title{
Genetic study of biotin biosynthesis in the obligate methanol-oxidizing bacterium 'Methylobacillus flagellatum'
}

\author{
I. G. Serebriiski and Y. D. Tsygankov
}

Author for correspondence: I. G. Serebriiski. e-mail: lab1@vnigen.msk.su

Laboratory of Genetics of Methylotrophic Microorganisms, Institute of Genetics and Selection of Industrial Micro-organisms, 1st Dorozhny proezd 1, Moscow 113545, Russia

\begin{abstract}
Twenty-seven mutants defective in the biosynthesis of biotin were generated by $N$-methyl- $N^{\prime}$-nitro- $N$-nitrosoguanidine treatment of the obligate methylotrophic bacterium 'Methylobacillus flagellatum'. The metabolic lesion in some of these mutants was determined in cross-feeding experiments using known Escherichia coli bio mutants. R-prime plasmids carrying various fragments of the ' $M$. flagellatum' chromosome were used for complementation of bio mutations in ' $M$. flagellatum' and $E$. coli. By complementation analysis and cross-feeding experiments, ' $M$. flagellatum' Bio- mutants were classified into five groups: bioA, bioB, bioD, bioH, and a group with unidentified bio mutations (biof or/and bioC). Using R-prime complementation mapping and also Hfr-like mapping, most of the bio genes of 'M. flagellatum' identified in this study were localized on the ' $M$. flagellatum' chromosome.
\end{abstract}

Keywords: 'Metbylobacillus flagellatum', biotin biosynthesis, obligate methylotroph, in vivo cloning, mutant selection

\section{INTRODUCTION}

Recently, the genetics of biotin biosynthesis has been extensively studied in enterobacteria and bacilli. It has been shown that six structural genes are specifically involved in the biotin synthetic pathway in Escherichia coli (Barker \& Campbell, 1980). Products of the genes bio A, bioB, bioD and bioF carry out the bioconversion of pimelylCoA into biotin (Eisenberg, 1987). Two other genes, bioC and $b i o H$, are involved in pimelyl-CoA synthesis (Fig. 1). In bacilli, the last four steps are analogous to those in $E$. coli (Pai, 1975). In addition, three new genes have been identified: bioW, which encodes pimelyl-CoA synthetase, and bioX and bio $Y$, encoding proteins with unknown functions (Gloeckler et al., 1990). The classical operon model of Jacob and Monod is applicable to the biotin biosynthetic (bio) operon, which consists of the genes bio $A B F C D$, in enterobacteria (Eisenberg, 1987; Sakurai et al., 1993). The bio locus in E. coli maps near the lambda attachment site at $18 \mathrm{~min}$ on the chromosome, while the unlinked gene, bioH, is located at $75 \mathrm{~min}$ (Rolfe \& Eisenberg, 1968).

At present, little is known about the biosynthesis of biotin in methylotrophs. Genetic analysis of these bacteria by traditional means has only recently appeared possible, as mutants were difficult to obtain and chromosome-mobilizing plasmids were rare (Holloway, 1984). An approach called complementation mapping has been used for isolation and characterization of extended genome fragments of Metbylopbilus metbylotropbus and "Metbylophilus viscogenes' (Moore et al., 1983; Lyon et al., 1988).

'Metbylobacillus flagellatum' is a Gram-negative obligate methylotroph able to use methanol and methylamine as sole sources of carbon and energy. Considerable progress has been made in the physiological, biochemical and genetical characterization of this bacterium (Gomelsky et al., 1990; Tsygankov et al., 1990a, b; Kiriukhin et al., 1993). Here we describe the isolation of $\mathrm{Bio}^{-}$mutants of ' $M$. flagellatum', their characterization, and mapping of some bio mutants by classical and 'surrogate' (Holloway, 1984) genetics.

\section{METHODS}

Bacterial strains and plasmids, growth and mutagenesis conditions. The E. coli and ' $M$. flagellatum' strains employed are listed in Table 1. Methylotrophic bacteria were cultured in a previously described minimal medium (Tsygankov \& Kazakova, 1987) with methanol (M9M) as sole source of carbon and energy. E. coli was grown in LB medium in the presence of appropriate antibiotics. Optimal conditions described earlier (Tsygankov \& Kazakova, 1987) were used for $N$-methyl- $N^{\prime}$ nitro- $N$-nitrosoguanidine (NTG) mutagenesis of ' $M$. flagellatum'.

Cross-feeding experiments. Testing agar plates were prepared 


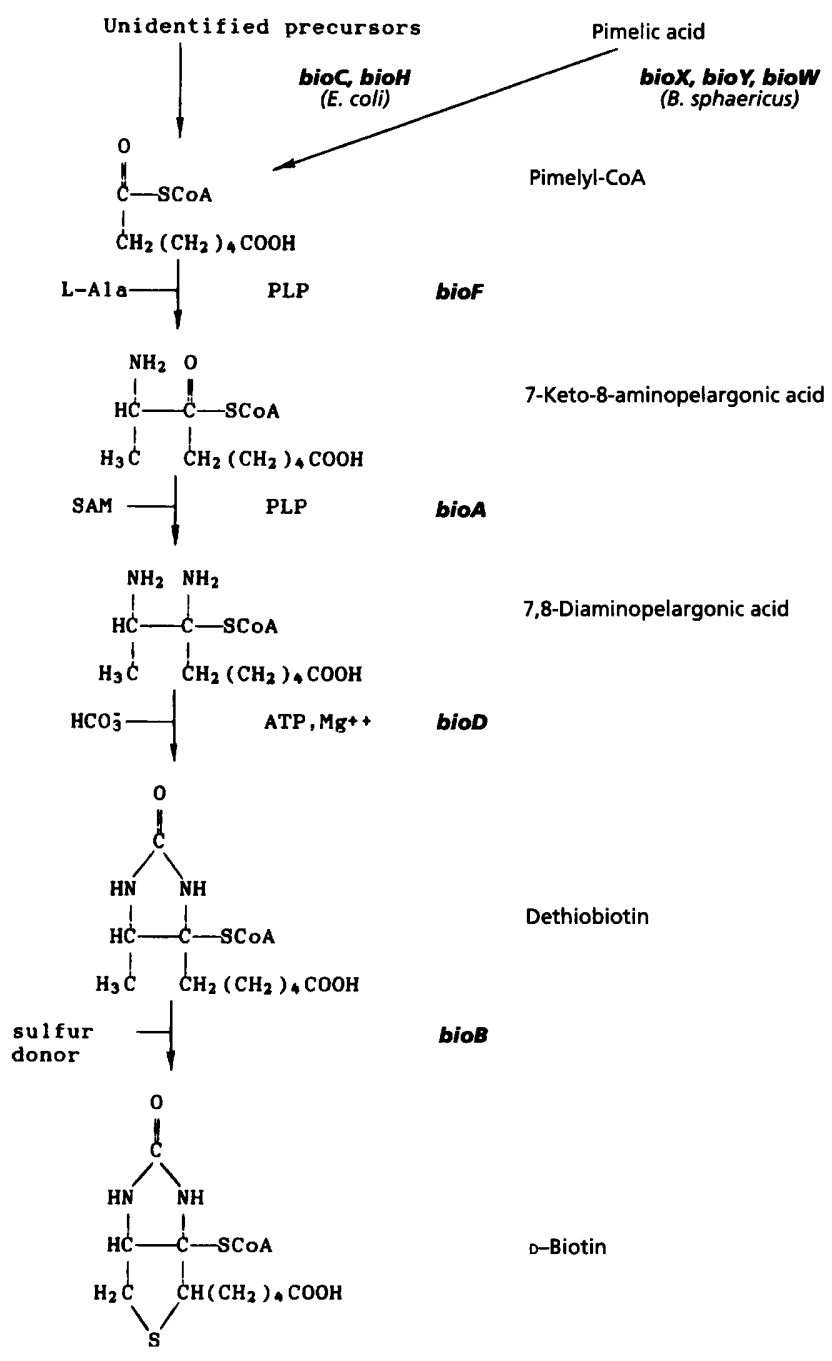

Fig. 1. Biotin biosynthetic pathway in E. coli and Bacillus sphaericus.

with M9 medium, containing glucose $(1 \%$, w/v), agar $(0.6 \%)$, vitamin-free Casamino acids $\left(2 \mathrm{~g}^{-1}\right)$ and 2,3,5-triphenyl tetrazolium blue $\left(50 \mathrm{mg} \mathrm{l}^{-1}\right)$, and washed cells of the corresponding $\mathrm{Bio}^{-}$mutant of E. coli. After the medium had solidified, drops of supernatants of tested cultures, grown overnight in M9 without biotin, were placed onto the plate. When biotin or its biosynthetic intermediates were excreted by ' $M$. flagellatum' in quantities large enough to cross-feed a test strain, its growth was observed by the appearance of a blue colour, resulting from reduction of tetrazolium dye. The size of the zone was dependent on the concentration of biotin (or its biosynthetic intermediate) and the length of the incubation period.

Conjugational crosses. These were carried out as described earlier (Tsygankov et al., 1990a). Derivatives of E. coli mutant strains, containing a $\operatorname{rec} A$ mutation, were obtained in conjugational crosses using E. coli HfrKL16 rec $A 56$ stlC:: Tn 10 as a donor. R-prime plasmids were selected in heterospecific crosses between previously described (Tsygankov et al., 1990a) donor 'M. flagellatum' MFK65 and $\operatorname{RecA}^{-} \mathrm{Bio}^{-}$E. coli strains.

Interrupted matings. Wild-type ' $M$. flagellatum' strains MFK64 (Serebrijski et al., 1989) and MFK95 (Tsygankov et al., 1990b) carrying chromosomally-integrated plasmid pAS8-121 were used as donors. Interrupted matings were carried out on filters. Interruptions were performed at various times after mixing donor and recipient by vigorously vortexing for $1 \mathrm{~min}$. The samples were incubated overnight in non-selective medium containing streptomycin $\left(3.5 \mathrm{mg} \mathrm{ml}^{-1}\right)$ for donor counterselection. The washed-off cultures were then plated onto selective media to determine the numbers of donor, recipient and recombinant cells (samples or known quantities of biotin were added to minimal liquid medium tubes seeded with $E$. coli strain R871, and the optical densities of the overnight cultures were compared).

Measurement of intracellular (free and bound) biotin. To extract free intracellular biotin, ' $M$. flagellatum' cells (harvested from $1.5 \mathrm{ml}$ of overnight culture) were washed once with phosphate buffer $(50 \mathrm{mM}, \mathrm{pH} 6.8)$ and boiled in distilled water for $5 \mathrm{~min}$. The biotin concentration of the supernatant was determined by microbiological assay. To extract bound biotin, washed cells were hydrolysed with $0.5 \mathrm{ml} 3 \mathrm{M} \mathrm{H}_{2} \mathrm{SO}_{4}$ at $121^{\circ} \mathrm{C}$ for $30 \mathrm{~min}$. After the hydrolysate had been neutralized to $\mathrm{pH} 6.8$ with $\mathrm{NaOH}$, the biotin concentration was measured by microbiological assay.

\section{RESULTS}

\section{'M. flagellatum' intracellular biotin content, biotin excretion and biotin degradation}

Biotin can be synthesized, accumulated and excreted by some micro-organisms, while other species do not excrete it or are unable to synthesize the biotin required for their growth. Wild-type ' $M$. flagellatum', a biotin prototroph, was tested in cross-feeding experiments with E. coli R874. The results showed that ' $M$. flagellatum' did not excrete biotin or its biosynthetic intermediates in detectable amounts.

Intracellular biotin concentrations in cultures of ' $M$. flagellatum' and (for comparison) of E. coli grown in the absence of exogenous biotin were examined. In the wildtype ' $M$. flagellatum' strain MFK1, the majority of intracellular biotin was assayable only after acid hydrolysis. The total intracellular biotin content of the ' $M$. flagellatum' cells was very similar to that of E. coli TG1 cells: about $4.5 \mathrm{ng}$ biotin per $\mathrm{mg}$ cells (dry weight).

Some micro-organisms are known to degrade D-biotin to bisnorbiotin and tetranorbiotin via $\beta$-oxidation (Iwahara et al., 1969). When ' $M$. flagellatum' MFK1 was grown overnight in a minimal medium containing methanol in the presence of $\mathrm{D}$-biotin at $1-10 \mu \mathrm{g} \mathrm{l}^{-1}$, no decrease in its concentration was detectable, indicating a lack of biotindegrading activity.

\section{Isolation of mutants defective in biotin biosynthesis and determination of metabolic lesions in some of these mutants}

Although the biotin requirement of different bacteria is as low as 5-50 $\mu \mathrm{g} \mathrm{l}^{-1}$ (Eisenberg, 1985), our attempts to select $\mathrm{Bio}^{-}$mutants of ' $M$. flagellatum' using this range of biotin concentrations were unsuccessful. Only after increasing the concentration of biotin about $10^{3}$-fold (up to $25 \mathrm{mg} \mathrm{l}^{-1}$ ) did we succeed in isolation of $17 \mathrm{Bio}^{-}$mutants. Using a medium containing dethiobiotin, a direct pre- 
Table 1. Strains and plasmids used in this study

\begin{tabular}{|c|c|c|}
\hline Strain & Relevant genotype/phenotype & Source/reference \\
\hline \multicolumn{3}{|l|}{ Escherichia coli } \\
\hline HFR KL-16 & $\operatorname{rec} A 56$ stlC $:: \operatorname{Tn} 10$ & Laboratory collection \\
\hline $\mathrm{R} 871$ & bioB2 & Cleary \& Campbell (1972) \\
\hline $\mathrm{R} 874$ & bioF12 & Cleary \& Campbell (1972) \\
\hline $\mathrm{R} 874 \mathrm{r}$ & bioF12 $\operatorname{rec} A 56$ stlC : $: \operatorname{Tn} 10$ & This study \\
\hline $\mathrm{R} 877$ & bioD19 & Cleary \& Campbell (1972) \\
\hline $\mathrm{R} 878$ & bioC23 & Cleary \& Campbell (1972) \\
\hline $\mathrm{R} 878 \mathrm{r}$ & bioC23 $\operatorname{rec} A 56$ stlC: $: \operatorname{Tn} 10$ & This study \\
\hline $\mathrm{R} 879$ & bio $A 24$ & Cleary \& Campbell (1972) \\
\hline BM355 & bioH::Mucts pro & Barker \& Campbell (1980) \\
\hline AT2687 & bio $A 1$ met $B 1$ & Laboratory collection \\
\hline AT2687r & bio $A 1$ metB1 rec $A 56$ stlC:: $\operatorname{Tn} 10$ & This study \\
\hline L37 & thi thr ilvC & Laboratory collection \\
\hline \multicolumn{3}{|l|}{ 'Methylobacillus } \\
\hline \multicolumn{3}{|l|}{ flagellatum' } \\
\hline \multicolumn{3}{|l|}{ (laboratory collection) } \\
\hline MFK3 & leu-1 str-1 & Tsygankov \& Kazakova (1987) \\
\hline MFK75 & leu-1 ilv A1 str-1 nal-7 & $\mathrm{Nal}^{\mathrm{R}}$ derivative of MFK19 \\
\hline MFK64 & $\operatorname{Hfr} A\left(\mathrm{Km}^{\mathrm{R}} \mathrm{Tc}^{\mathrm{R}} \mathrm{Sm}^{\mathrm{R}} \mathrm{Tp}^{\mathrm{R}}\right)$ & Serebrijski et al. (1989) \\
\hline MFK65 & Plasmid pULB113 & Tsygankov et al. (1990a) \\
\hline MFK77 & gen-1, plasmid R68.45 & Kletsova \& Tsygankov (1990) \\
\hline MFK95 & $\mathrm{HfrB}\left(\mathrm{Km}^{\mathrm{R}} \mathrm{Tc}^{\mathrm{R}} \mathrm{Sm}^{\mathrm{R}} \mathrm{Tp}^{\mathrm{R}}\right)$ & Tsygankov et al. (1990b) \\
\hline \multicolumn{3}{|l|}{$\begin{array}{l}\text { Biotin mutants of } \\
\text { 'M. flagellatum' obtained } \\
\text { in this study }\end{array}$} \\
\hline MFK29-40 & leu-1 str-1 (common genotype) & NTG treatment of MFK3 \\
\hline MFK24 & bio-3 & \\
\hline MFK25 & bio $A 2$ & \\
\hline MFK26 & bioB1 & \\
\hline MFK27 & bio-4 & \\
\hline MFK28 & bio-5 & \\
\hline MFK33 & bioD1 & \\
\hline MFK36 & bio $A 1$ & \\
\hline MFK29-32, 34, 35, 37-40 & bioB2: 10 & \\
\hline MFK60 & bioB1 rif-14 nal-4 & $\mathrm{Rif}^{\mathrm{R}} \mathrm{Nal}^{\mathrm{R}}$ derivative of MFK26 \\
\hline MFK61 & bio $A 1$ rif-15 nal-5 & $\mathrm{Rif}^{\mathrm{R}} \mathrm{Nal}^{\mathrm{R}}$ derivative of MFK 36 \\
\hline MFK85-94 & $\begin{array}{l}\text { leu-1 str-1 ilv A1 nal-7 } \\
\text { (common genotype) }\end{array}$ & NTG treatment of MFK 75 \\
\hline MFK85 & bioD2 & \\
\hline MFK86 & bio $A 3$ & \\
\hline MFK87 & bio $A 4$ & \\
\hline MFK88-90 & bioD3:5 & \\
\hline MFK91-94 & bio-6:9 & \\
\hline \multicolumn{3}{|l|}{ Plasmids } \\
\hline pULB113 & IncP1, $\mathrm{Km}^{\mathrm{R}} \mathrm{Tc}^{\mathrm{R}} \mathrm{Ap} \mathrm{p}^{\mathrm{R}}$ & Lejeune et al. (1983) \\
\hline R68.45 & IncP1, $\mathrm{Km}^{\mathbf{R}} \mathrm{Tc}^{\mathrm{R}} \mathrm{Ap^{ \textrm {R } }}$ & Haas \& Holloway (1976) \\
\hline
\end{tabular}

cursor of biotin, we selected 10 other mutants. The frequency of mutant isolation was $0.54 \%$ on biotin and $0.1 \%$ on dethiobiotin. The level of reversions to the wild phenotype for all bio mutations did not exceed $10^{-8}$ per cell. Three of the mutants demonstrated a leaky phenotype. The minimal requirements of the mutants for biotin and dethiobiotin were 8 and $4 \mathrm{mg} \mathrm{l}^{-1}$, respectively. Some of the mutants were able to grow in the presence of either biotin or dethiobiotin, while others grew only in the presence of biotin. The ability of mutants to be complemented only by biotin indicates a lesion in bioB, responsible for synthesis of biotin synthetase. 
Table 2. Analysis of the ' $M$. flagellatum' Bio' mutants in cross-feeding experiments with known bio mutants of $E$. coli

\begin{tabular}{|c|c|c|c|c|}
\hline & \multirow[b]{2}{*}{ MFK75 } & \multicolumn{3}{|c|}{ 'M. flagellatum' mutants: } \\
\hline & & $\begin{array}{c}29-32,34 \\
35,37-40\end{array}$ & $61,80,85-90$ & $82-84$, 91-94 \\
\hline \multicolumn{5}{|l|}{ Fed by: } \\
\hline Biotin & $\mathrm{bio}^{+}$ & + & + & + \\
\hline Dethiobiotin & $\mathrm{bio}^{+}$ & - & + & + \\
\hline Pimelate & $\mathrm{bio}^{+}$ & - & - & - \\
\hline \multicolumn{5}{|c|}{ Feeding of $E$. coli mutants } \\
\hline bioB & - & - & - & - \\
\hline bioD, bio $A$ & - & + & - & - \\
\hline bioC, bioF, bioH & - & + & + & - \\
\hline Classified as & & $b i o B$ & bioD, bio $A$ & $\begin{array}{l}\text { Defective in some } \\
\text { early steps }\end{array}$ \\
\hline
\end{tabular}

Neutralized pimelic acid $\left(0.5-50 \mu \mathrm{g} \mathrm{ml}^{-1}\right)$ was used as a supplement in order to detect mutants dependent on pimelate for their biotin prototrophy; none of the mutants among our collection showed a strict requirement for this compound.

The amount of biotin biosynthetic intermediates excreted into the growth medium was insufficient to cross-feed the ' $M$. flagellatum' mutants. In order to establish the metabolic blocks in the rest of the mutants, we carried out cross-feeding experiments using known bio mutants of E. coli. The results of these experiments are shown in Table 2.

The results of cross-feeding experiments using supernatants did not allow us to distinguish between bio $A$ and bioD mutants. This may be because the amount of 7,8-diaminopelargonic acid excreted by bioD mutants of ' $M$. flagellatum' is not sufficient to feed a bio $A$ mutant of E. coli, while the amount of 7-keto-8-aminopelargonic acid excreted by ' $M$. flagellatum' cells at the same time is sufficient to feed the mutants of $E$. coli defective in the earlier stages of biotin biosynthesis (bioF, $C, H)$.

The addition of pimelic acid to the culture medium of several different micro-organisms has been shown to enhance the biosynthesis of biotin and its intermediates (Izumi et al., 1980). Interestingly, no increase in excretion of biotin or its intermediates was observed after the addition of pimelate $\left(0.5-50 \mathrm{mg} \mathrm{l}^{-1}\right)$ to ' $M$. flagellatum' cultures (tested in a cross-feeding experiment with $E$. coli R874; data not shown). The experiments described above made it possible to divide all the bio mutants of ' $M$. flagellatum' into three large groups.

\section{Cloning of some of the bio genes of ' $M$. flagellatum' in R-prime plasmids}

A library consisting of $253 \mathrm{R}$-prime plasmids (Tsygankov et al., 1990a) carrying various fragments of the ' $M$. flagellatum' chromosome contained R-prime plasmids able to complement 33 auxotrophic mutations of E. coli, 17 of
'M. Alagellatum' and 3 of Pseudomonas aeruginosa. $\mathrm{R}$ 'pro $A$ plasmids selected using E. coli AB2463 complemented mutations bioB1-11 in ' $M$. flagellatum' and bioB2 in E. coli R871. These plasmids also complemented bioD and bioH mutations in E. coli R877 and BM355 and six mutations of ' $M$. flagellatum' (see Table 3), but did not complement any other bio mutations in the E. coli strains tested.

None of the R-prime plasmids in our library were able to complement bio $A, F, C$ mutations in $E$. coli, or some unidentified bio mutations in ' $M$. Alagellatum', which indicated that the range of R-prime plasmids available was probably insufficient for complementation of all bio mutations of ' $M$. flagellatum'. We therefore attempted to obtain R-prime plasmids carrying bio $A$, bioF and bioC by separate selection using complementation of corresponding recipient strains of $E$. coli.

Our preliminary data on constructing R-prime plasmids carrying fragments of the ' $M$. flagellatum' chromosome indicated their instability in $\operatorname{rec} A^{+} E$. coli hosts. In order to obtain stable $\mathrm{R}$-prime plasmids we constructed $\operatorname{rec} A^{-}$ derivatives of E. coli AT2687 (bio A1), R874 (bioF12) and R878 (bioC23). A previously described donor strain of ' $M$. flagellatum' was employed in heterospecific crosses for selection of R-prime plasmids.

Five $\mathrm{R}^{\prime}$ bio $A$ plasmids were selected by complementation of the bio $A 1$ mutation in recipient strain AT2687, and their ability to transfer the bio $A$ marker into a Rif $^{\mathrm{R}}$ derivative of the same strain was tested. All five clones showed the $\mathrm{Km}^{\mathrm{R}} \mathrm{Ap}^{\mathrm{R}}$ phenotype determined by the plasmid antibiotic resistance genes. All $\mathrm{R}^{\prime} b i o A$ plasmids also complemented the bio A24 mutation in E. coli $\mathrm{R} 879$ (and four mutations of ' $M$. flagellatum'; see Table 3), but none of the other bio mutations tested. Stable R-prime plasmids were not found among the transconjugants obtained in crosses with bioF and bio C mutants of E. coli. These results suggested that at least four genes involved in biotin biosynthesis in ' $M$. flagellatum' had been cloned on R-prime plasmids. 
Table 3. Classification of the Bio- mutants of ' $M$. flagellatum'

\begin{tabular}{|c|c|c|c|c|c|}
\hline \multirow[t]{2}{*}{ Characteristics of mutants } & \multicolumn{5}{|c|}{ Mutants in groups I-V: } \\
\hline & $\begin{array}{c}I \\
29-32 \\
34,35 \\
37-40\end{array}$ & $\begin{array}{c}\text { II } \\
80,85 \\
88-90\end{array}$ & $\begin{array}{c}\text { III } \\
82,83, \\
93,94\end{array}$ & $\begin{array}{c}\text { IV } \\
61,81 \\
86,87\end{array}$ & $\begin{array}{c}\mathrm{V} \\
84,91 \\
92\end{array}$ \\
\hline Growth on dethiobiotin & - & + & + & + & + \\
\hline Complemented with $\mathrm{R}^{\prime}$ pro $A$ & + & + & + & - & - \\
\hline Complemented with $\mathrm{R}^{\prime}$ bio $A$ & - & - & - & + & - \\
\hline Feeds E. coli bioF & + & + & - & + & - \\
\hline Identified as: & bioB & bioD & $\begin{array}{l}\text { bioH (or/ } \\
\text { and bioC, } \\
\text { bioF) }\end{array}$ & $\operatorname{bio} A$ & $\begin{array}{l}\text { bioC or/ } \\
\text { and bioF }\end{array}$ \\
\hline
\end{tabular}

\section{Classification of the bio mutations of ' $M$. flagellatum'}

In order to classify the $\mathrm{Bio}^{-}$mutants of ' $M$. flagellatum' we complemented them with the R-prime plasmids described above. One group of mutants was complemented by $\mathrm{R}^{\prime}$ pro $A$, the other by $\mathrm{R}^{\prime}$ bio $A$. Some mutants were not complemented by any of the R-prime plasmids. No mutants could be complemented by both kinds of $\mathrm{R}$ prime plasmids. Based on the complementation data and feeding tests, all $\mathrm{Bio}^{-}$mutants could be divided into five groups (Table 3 ).

It is important to note that while groups I, II and IV are identified unequivocally, group III can be identified as bioH only if we assume that all the ' $M$. flagellatum' genes carried by R-prime plasmids can be expressed effectively in $E$. coli. Otherwise, bio $C$ or bioF mutants could also be present in group III. Although mutants belonging to groups III and V show different patterns of complementation by R-prime plasmids, cloning of individual ' $M$. flagellatum' genes is needed to classify the mutations precisely.

\section{Mapping of bio mutations of ' $M$. flagellatum'}

Complementation mapping of bioB, $D, H$ mutations of ' $M$. flagellatum'. All $29 \mathrm{R}^{\prime}$ pro $A$ plasmids complemented the bioB2, bioD19 and bioH mutations in corresponding $E$. coli strains; 16 of them also complemented the $\arg E 3$ mutation in E. coli AB2463. Seven of $47 \mathrm{R}^{\prime}$ argE plasmids complemented the pro $A 2$ mutation, but none complemented bio $B$ mutations. It could be concluded that ' $M$. flagellatum' genes complementing these mutations are linked and their order is CargE3-CproA2-bioB1 [' $M$. flagellatum' genes identified by complementation of E. coli strains, according to Lyon et al. (1988), are indicated by the prefix C]. The established order was confirmed by the results of analysis of linkage with marker ilvC in strain L37. One $\mathrm{R}^{\prime}$ pro $A$ plasmid, but none of the $\mathrm{R}^{\prime}$ argE plasmids complemented the mutation, which places $i l v C$ next to bio $B$, making the most likely gene order as follows: CargE3-CproA2bioB-CilvC. The data obtained allow us to place three of the ' $M$. flagellatum' bio genes mentioned above into a large group of 15 auxotrophic genes determined earlier (Tsygankov et al., 1990a) (see Fig. 2).

Mapping of the bioA mutation in ' $M$. flagellatum'. The $\mathrm{R}^{\prime}$ bio $A$ plasmids were further tested for the ability to complement various mutations in $E$. coli and ' $M$. flagellatum' strains defective in the biosynthesis of amino acids, vitamins and nucleotides. No linkage was revealed with 38 different markers tested. Restriction analysis of Rprime plasmids has shown that they carried inserts of about $15 \mathrm{~kb}$ (data not shown).

For chromosomal mapping of various Gram-negative bacteria the IncPI plasmids are often used; these mediate unorientated chromosome mobilization and thus allow determination of the cotransfer frequencies of different markers. Although the determination of true marker linkage values can be hampered by retroconjugant formation (Mergeay et al., 1987), a system of chromosome mobilization with the aid of the IncP1 plasmid R68.45 was successfully applied for mapping of methylotrophs. In homologous matings the linkage of C-1 genes of Metbylobacterium AM1 (Tatra \& Goodwin, 1985) and of ' $M$. flagellatum' (Kletsova \& Tsygankov, 1990) with different antibiotic resistance and auxotrophic markers was determined.

We employed the system of chromosome mobilization using R68.45 to determine the linkage of ' $M$. flagellatum' bio $A$ markers with ilv $A 1$ and leu-1, which belong to the early and late chromosome regions, respectively (Serebrijski et al., 1989). Analysis of recombinant classes, obtained in the matings described earlier (Kletsova \& Tsygankov, 1990), has shown that the leu-1 marker (and a group of nine other linked markers) is not linked to bio $A 1$. These data were confirmed by the results of analysis of cotransfer frequencies of unselected markers in matings between wild-type donor (MFK 77) and mutant MFK86. No linkage was found between bio $A 2$ and ilv $A 2$ (data not shown).

The results of ' $M$. flagellatum' chromosome mapping (Tsygankov et al., 1990a) are consistent with the idea of 


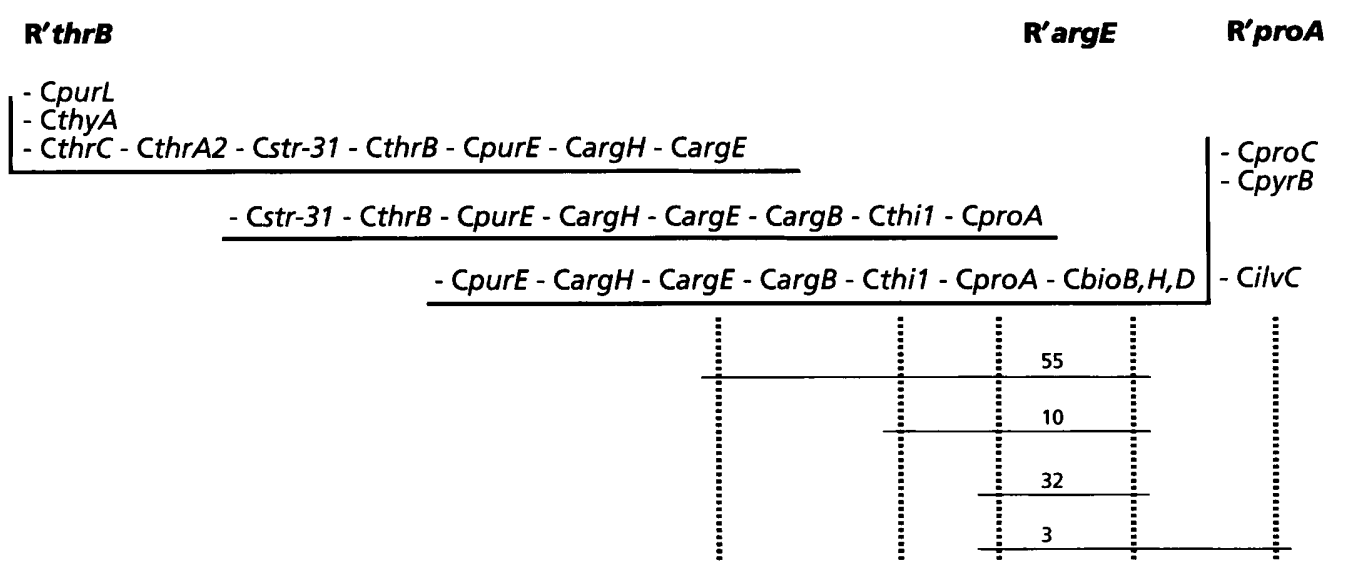

Fig. 2. Results of the analysis of individual $R^{\prime} p r o A$ plasmids and localization of three biotin genes in the linkage group. Numbers are the percentage of prime plasmids carrying the corresponding markers (27 plasmids were analysed). The arrangement of 18 markers into three overlapping linkage groups was established by R-prime complementation as described by Tsygankov et al (1990a). C denotes that the ' $M$. flagellatum' gene was identified by complementation of E. coli strains.

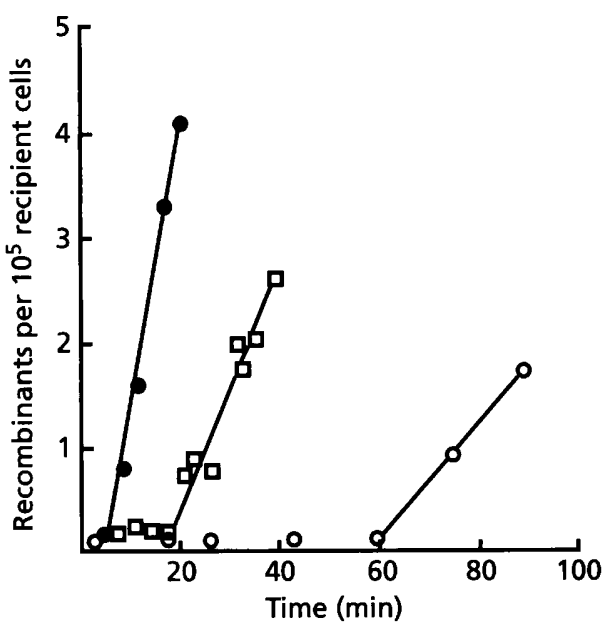

Fig. 3. Time of entry trends. ' $M$. flagellatum' MFK64 (wild-type, pAS8-121) was mated with MFK60 (leu-1 bioB1) and MFK61 (leu-1 bioA1). The number of recombinants inheriting the wildtype allele of the donor is shown for each sample time. bioB1 (6 min); $\square$, bioA1 $(17 \mathrm{~min}) ; 0, l e u-1$ (the common marker, $60 \mathrm{~min}$ ).

the existence of auxotroph-rich regions on chromosomes of methylotrophic bacteria, analogous to that found in Pseudomonas spp. (Holloway \& Morgan, 1986). The bio $A$ gene is probably outside such regions.

Time of entry mapping of bio genes. Two Hfr-like donor strains of ' $M$. flagellatum' were used for mapping bio genes in time units. In interrupted matings using ' $M$. flagellatum' MFK64 (HfrA) (Serebrijski et al., 1989) the time of entry for bioB1 and bio $A 1$ was determined at 6 and $17 \mathrm{~min}$, respectively (Fig. 3). The chromosome transfer origin of strain MFK95 (HfrB) (Tsygankov et al., 1990b) was found between $b i o B$ and bio $A$ (bio $A$ is the first transferred marker of $\mathrm{HfrB}, 5 \mathrm{~min})$. Nevertheless, in the limits of a relatively small ' $M$. flagellatum' genome region, the precision of the genetic map can be satisfactory even using a single donor. The time of entry for the bio-5 marker was determined at $6 \mathrm{~min}$, very close to bioB1 (kinetics not shown). We were not able to map bio-6 and bio-7 due to their leaky phenotype.

\section{DISCUSSION}

For reasons not yet entirely clear, mutants of methylotrophic bacteria are hard to obtain. This study confirms the efficiency of an approach for isolation of auxotrophic mutants in methylotrophs that was worked out earlier (Tsygankov \& Kazakova, 1987). A representative collection of $\mathrm{Bio}^{-}$mutants of ' $M$. flagellatum' was obtained using media containing individual intermediates of biotin synthesis in high concentrations.

The absence of influence of pimelic acid and the extrahigh requirements of ' $M$. flagellatum' mutants for biotin, dethiobiotin and other biosynthetic intermediates of biotin on the one hand, and the low intracellular biotin content on the other, make it necessary to study the permeability of ' $M$. flagellatum' cells for these compounds and the regulation of biotin biosynthesis.

The present study provides preliminary information on the biotin biosynthetic pathway in ' $M$. flagellatum'. Complementation of an E. coli bioH mutant indicates that the early steps of biotin biosynthesis could be similar to those operating in E. coli.

A complication in the genetic analysis of methylotrophs, especially the obligate methylotrophs, has been the absence of a natural system of gene transfer, analogous to E. coli $\mathrm{Hfr}$ donors. The construction of Hfr-like donors and the development of an interrupted mating method (Tsygankov et al., 1990a), in combination with complementation mapping using R-prime plasmids, has enabled us to build the first circular chromosome map of an 
obligate methylotroph ('M. flagellatum'). Our current data allowed us to put five additional (bio) markers on this map. Our data demonstrate that, unlike in E. coli, the bio $A$ gene is not linked to the bioB and bioD genes in ' $M$. flagellatum'. Conversely, while in E. coli bioH is located far from the bio $A-D$ operon, it is closely linked to the $b i o B$ and bio $D$ genes in ' $M$. flagellatum'. The location of other ' $M$. flagellatum' bio genes is still unknown. At least four bio genes are clustered on the ' $M$. flagellatum' chromosome (bioBDH genes and one of the genes of early stages of biotin biosynthesis). Whether the genes are organized in an operon structure has yet to be determined. Cloning and study of individual genes, which is currently in progress, may help to clarify this.

\section{ACKNOWLEDGEMENTS}

We are greatly indebted to Professor Allan Campbell (Stanford University, CA, USA) for generously providing us with E. coli bio mutants. We thank S. Guskova for excellent technical assistance, and S. Kazakova, L. Kletsova and O. Reyes for their continuous interest and help with preparation of the manuscript.

\section{REFERENCES}

Barker, D. F. \& Campbell, A. M. (1980). Use of bio-lac fusion strains to study regulation of biotin biosynthesis in Eschericbia coli. $J$ Bacteriol 143, 789-800.

Cleary, P. \& Campbell, A. M. (1972). Deletion and complementation analysis of the biotin gene cluster of Escherichia coli. J Bacteriol 112, 830-839.

Eisenberg, M. A. (1985). Regulation of the biotin operon in E. coli. Part IV. Biotin synthesis and metabolism, biotin as molecular probe. Ann NY Acad Sci 447, 335-349.

Eisenberg, M. A. (1987). Biosynthesis of biotin and lipoic acid. In Eschericbia coli and Salmonella typhimurium: Cellular and Molecular Biology, pp. 544-550. Edited by F. C. Neidhart, J. L. Ingraham, K. B. Low, B. Magasanik, M. Schaechter \& M. E. Umbarger. Washington, DC: American Society for Microbiology.

Gloeckler, R., Ohsawa, I., Speck, D., Ledoux, C., Bernard, S., Zinsius, M., Villeval, D., Kisou, T., Komogawa, K. \& Lemoine, U. (1990). Cloning and characterization of the Bacillus sphaericus genes controlling the bioconversion of pimelate into dethiobiotin. Gene 87, 63-70.

Gomelsky, M., Gak, E., Chistoserdov, A., Bolotin, A. \& Tsygankov, Y. D. (1990). Cloning, sequence and expression in Escherichia coli of the Metbylobacillus flagellatum $\operatorname{rec} A$ gene. Gene 94, 69-75.

Haas, D. \& Holloway, B. W. (1976). R factor variants with enhanced sex factor activity in Pseudomonas aeruginosa. Mol \& Gen Genet 144, 243-251.

Holloway, B. W. (1984). Genetics of methylotrophs. In Methylotropbs: Microbiology, Biochemistry, and Genetics, pp. 87-106. Edited by C. Hou. Boca Raton, FL: CRC Press.

Holloway, B. W. \& Morgan, A. F. (1986). Genome organization in Pseudomonas. Annu Rev Microbiol 40, 79-105.

Iwahara, S., McCormick, D. B., Wright, L. D. \& Li, H. C. (1969). Bacterial degradation of biotin. J Biol Chem 244, 1393-1398.
Izumi, Y., Tani, Y. \& Yamada, H. (1980). Biotin biosynthesis in microorganisms. Bull Inst Chem Res Kyoto Univ 58, 434-447.

Kiriukhin, M. Y., Detkov, S. Y., Baev, M. V. \& Tsygankov, Y. D. (1993). Citrate synthase from the obligate methylotroph Metbylobacillus flagellatum. FEMS Microbiol Lett 113, 101-106.

Kletsova, L. V. \& Tsygankov, Y. D. (1990). Mapping of $p g i$ and $g p d$ genes involved in C-1 assimilation in the obligate methylotroph Metbylobacillus flagellatum. Arch Microbiol 153, 139-145.

Lejeune, P., Mergeay, M., van Gijsegem, F., Faelen, M., Certis, J. \& Toussaint, A. (1983). Chromosome transfer and R-prime plasmid formation mediated by plasmid pULB113 (RP4::mini-Mu) in Alcaligenes eutrophus $\mathrm{CH} 34$ and P. fuorescens 6.2. J Bacteriol 155, 1015-1026.

Lyon, B. R., Kearney, P. P., Sinclair, M. I. \& Holloway, B. W. (1988). Comparative complementation mapping of Methylophilus spp. using cosmid gene libraries and prime plasmids. J Gen Microbiol 134, 123-132.

Mergeay, M., Lejeune, P., Sadouk, A., Gerits, J. \& Fabry, L. (1987). Shuttle transfer (or retrotransfer) of chromosomal markers mediated by plasmid pULB113. Mol \& Gen Genet 209, 61-70.

Moore, A. T., Nayudu, M. \& Holloway, B. W. (1983). Genetic mapping in Metbylophilus methylotrophus AS1.J Gen Microbiol 129, 785-799.

Pai, C. H. (1975). Genetics of biotin synthesis in Bacillus subtilis. $J$ Bacteriol 121, 1-8.

Rolfe, B. \& Eisenberg, M. A. (1968). Genetic and biochemical analysis of the biotin loci of Escherichia coli K-12. J Bacteriol 96, 515-524.

Sakurai, N., Imai, Y. J., Masuda, M., Komatsubara, S. \& Tosa, T. (1993). Molecular breeding of a biotin-hyperproducing Serratia marcescens strain. Appl Environ Microbiol 59, 3225-3232.

Serebrijski, I. G., Kazakova, S. M. \& Tsygankov, Y. D. (1989). Construction of $\mathrm{Hfr}$-like donors of the obligate methanol-oxidizing bacterium Methylobacillus flagellatum KT. FEMS Microbiol Lett 59, 203-206.

Tatra, P. K. \& Goodwin, P. M. (1985). Mapping of some genes involved in C-1 metabolism in the facultative methylotroph Metbylobacterium sp. strain AM1 (Pseudomonas AM1). Arch Microbiol 143, 169-177.

Tsygankov, Y. D. \& Kazakova, S. M. (1987). Development of gene transfer systems in Metbylobacillus flagellatum KT: isolation of auxotrophic mutants. Arch Microbiol 149, 396-401.

Tsygankov, Y. D., Kazakova, S. \& Serebrijski, I. G. (1990a). Genetic mapping of the obligate methylotroph Methylobacillus flagellatum: characteristics of prime plasmids and the chromosome map in time units. J Bacteriol 172, 2747-2754.

Tsygankov, Y. D., Gomelski, M. V., Marchenko, G. N. \& Serebrijski, I. G. (1990b). Genetics of methylotrophs. In Proceedings, 6th International Symposium on Genetics of Industrial Microorganisms, pp. 645-656. Edited by H. Heslot and others. Strasbourg: Société Française de Microbiologie.

Received 8 August 1994; revised 20 February 1995; accepted 17 March 1995. 